\title{
Význam kvalifikací a kompetencí v profesním vzdělávání dospělých ${ }^{1}$
}

\section{Importance of qualifications and competences in vocational education of adults}

\author{
Michaela Tureckiová, Jaroslav Veteška
}

\begin{abstract}
Abstrakt: Př́spěvek v úvodní části shrnuje vývoj konceptu celoživotního učení, který je založen na formování a rozvíjení (klíčových) kompetencí. Tento přístup, prosazující se nyní nejen v České republice jako určující prvek kurikulární reformy, má delší tradici a opodstatnění v profesním vzdělávání dospělých a uplatňuje se v rozvoji lidských zdrojů. Příspěvek je proto dále věnován představení výsledků několika výzkumných šetření provedených právě $\mathrm{v}$ této oblasti a věnovaných požadavkům na kompetence manažerů a možnostem učení v inovativních pracovních organizacích v České republice. Konkrétně se jedná o výstupy $\mathrm{z}$ analýzy inzerce nabídky pracovních míst pro manažery a odborné specialisty a výzkumného šetření provedeného technikou ohniskových skupin a částečně strukturovaných rozhovorů s manažery firemního vzdělávání, jehož cílem bylo zjistit stav a predikovaný vývoj v oblasti vzdělávání a učení pracovníků.
\end{abstract}

Klíčová slova: celoživotní učení, kompetence, způsobilost, kvalifikace, kurikulární reforma, profesní vzdělávání dospělých, vzdělávání a učení pracovníků

\begin{abstract}
In its introductory part, the paper summarizes the development of the concept of competency-based lifelong learning. This approach, which is now becoming a determining element of the curriculum reform, has had a longer tradition and justification in the vocational education of adults and is applied in human resource development. The paper therefore further presents the results of several surveys dealing with requirements on managers' competencies and with learning possibilities in innovative working organisations in the Czech Republic. Specifically, this includes outputs from an analysis of job offers for managers and technical specialists and outputs from a survey made by a focus group technique and partially structured interviews with corporate education managers where the objective was to establish the situation and forecasted development in employees' education and learning.
\end{abstract}

Keywords: lifelong learning, competence, competency, qualifications, curriculum reform, vocational education of adults, employees' education and learning

\section{1 Úvod}

Model vzdělávání a rozvoje pracovníků založený na prokázaných a praxí požadovaných kompetencích je od poloviny 90. let 20. století považován za součást konceptu řízení (lidských zdrojů) podle kompetencí. Zhruba ve stejném období se nejprve v Severní Americe

\footnotetext{
${ }^{1}$ Př́íspěvek vznikl jako výstup z grantového projektu GA ČR „Andragogický model učení a vzdělávání dospělých založený na získávání a rozvoji klíčových kompetencí“ (registrační číslo 406/09/1950).
} 
(zpočátku zejména v Kanadě) a později i na jiných kontinentech rozšířilo pojetí (dalšího) profesního vzdělávání založeného právě na formování a dalším rozvoji takových kompetencí, jejichž aplikace umožní jednotlivci zajistit a zachovat si zaměstnání (zaměstnatelnost) a pracovním organizacím úspěšně fungovat. Koncept vzdělávání, vedoucího k obdobnému cíli, totiž $\mathrm{k}$ vytvoření a požadované míře rozvoje (klíčových) kompetencí se stává dominantním př́stupem také $\mathrm{v}$ počátečním vzdělávání. V České republice je dosud aplikován do úrovně všeobecného vzdělání a profesní přípravy probíhajících v rámci sekundárního vzdělávání.

Dlouhodobě je diskutována také reforma terciárního vzdělávání, a to nikoli jen v souvislosti vazby na předchozí typy počátečního vzdělávání, ale rovněž v rámci př́prav národní soustavy kvalifikací pro terciární vzdělávání. (srovnej např́íklad s Tureckiová, 2009 a Veteška, 2010) Ve výše uvedeném rámci lze považovat za významné reflektovat zkušenosti dalšího profesního vzdělávání, které vede k získávání a rozvoji kompetencí, také pro oblast vzdělávání počátečního a především právě terciárního, a to nikoli, i když významně z hlediska požadavku větší účasti vysokých škol na dalším vzdělávání a přiblížení kurikula terciárního vzdělávání požadavkům praxe.

\section{Přístup ke vzdělávání vedoucímu k osvojování a rozvíjení (klíčových) kompetencí}

Cílem tohoto příspěvku není podat vyčerpávající přehled metodologických a terminologických východisek konceptu, který významně ovlivňuje podobu celoživotního učení nejen v rámci euroamerického regionu. Tomu se podrobně věnujeme v jiných publikacích, např́iklad Tureckiová (2009), Veteška a Tureckiová (2008), Veteška et al. (2009) a Veteška (2010). Soustředit se chceme na oblast aplikace tohoto pojetí v širším rámci řízení a rozvoje lidských zdrojů podle kompetencí. Nicméně za užitečné považujeme uvedení rámcových souvislostí mezi počátečním a dalším vzděláváním z hlediska požadavků na formování a rozvoj (klíčových) kompetencí v jednotlivých fázích celoživotního učení (viz obrázek 1).

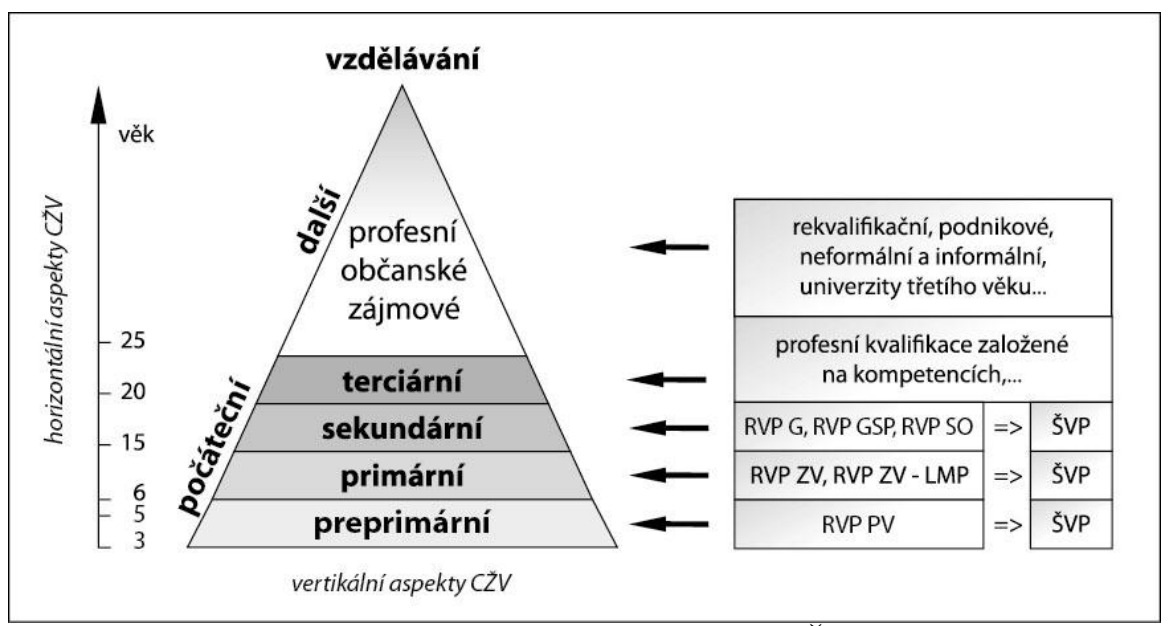

Obrázek 1. Pyramida celoživotního vzdělávání - aplikace v ČR

Zdroj: Veteška (2010).

Oblast formování a dalšího rozvíjení klíčových (generických a /sebe/reflexivních) kompetencí je v požadavcích celoživotního učení nad úroveň vzdělání základního postupně doplňována také o rozvíjení kompetencí profesních, a to částečně již $\mathrm{v}$ rámci všeobecného vzdělávání a dominantně v profesní prŕípravě a dalším profesním vzdělávání. Kompetencí, respektive kompetentností jednotlivce $\mathrm{v}$ tomto textu rozumíme ,jedinečnou schopnost člověka úspěšně 
jednat a dále rozvíjet svůj potenciál... v kontextu různých ... činností a ... situací, spojenou s ... motivací rozhodovat a nést za svá rozhodnutí odpovědnost". (srovnej s Veteška \& Tureckiová, 2008) K dalším charakteristikám dílčích kompetencí ve výše uvedeném významu patř́ také to, že kompetence jsou v současných kurikulárních dokumentech a klíčových dokumentech vzdělávací politiky EU považovány za jeden z rozhodujících výsledků učení (learning outcomes), jež jsou zásadně kontextualizované, multidimenzionální, s potenciálem pro akci a rozvoj a je možno je definovat standardem. (viz též Tremblay et al., 2002)

Formování a rozvíjení různých typů kompetencí (podrobněji Tureckiová, 2009) na všech úrovních celoživotního učení (ve vertikální i horizontální dimenzi) je rovněž prostředkem utváření a následného prohlubování, zvyšování nebo změn v kvalifikacích jednotlivců a jedním ze zásadních faktorů inovačního potenciálu každé společnosti. Vztah mezi kvalifikací a kompetencemi jednotlivce je znázorněn na obrázku 2, k němuž dodáváme, že v něm použité označení formální a neformální kvalifikace vychází z tradičního užívání těchto pojmů v české andragogické terminologii. (srovnej s Palán, 2002)

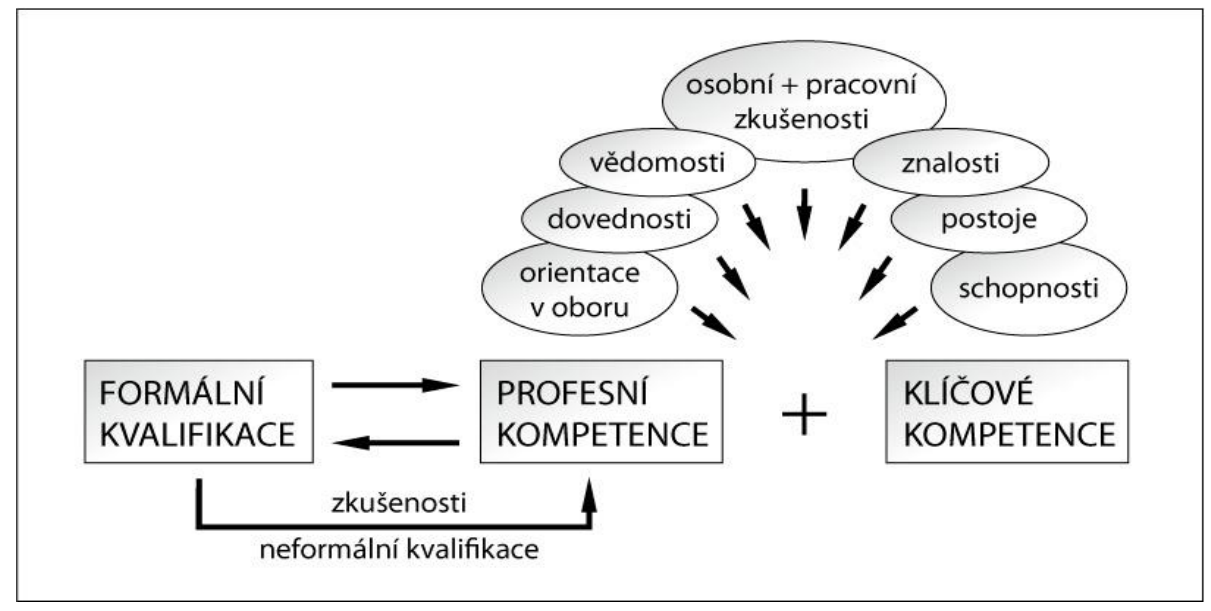

Obrázek 2. Nové pojetí kvalifikací založených na získávání klíčových kompetencí Zdroj: Veteška (2010, s. 101).

Potřeba nových kompetencí se většinou neobjeví neočekávaně a je možné je do značné míry předvídat, což potvrzují také výsledky dále uvedeného výzkumu (část 3). Organizace si potřeby nových kompetencí uvědomují. Aby k tomu nedocházelo až tehdy, kdy jejich absence ve firmě začne působit vážné problémy, je nezbytné aplikovat otevřený model systematického vzdělávání a rozvoje pracovníků, jehož př́íklad - vytvořený Tureckiovou na základě výsledků výzkumného šetření - je uveden dále v tomto př́spěvku (část 4). Zároveň s tím, je třeba konstatovat, že změna kvalifikací je rovněž možná, žádoucí a stává se realitou pro mnoho pracovníků. Rychleji obvykle tato změna probíhá na úrovni neformální kvalifikace, kde významnou roli sehrává právě svojí podstatou spíše neformální profesní vzdělávání dospělých. 


\section{Aktuální požadavky na kompetence manažerů a specialistů v podnicích $\mathbf{v}$ ČR}

Výzkum dynamiky měnících se požadavků na (klíčové) kompetence manažerů a odborných specialistů na trhu práce byl realizován Veteškou v roce 2009. Data získaná z tohoto výzkumu byla dále porovnána s údaji ze stejně zaměřeného průzkumu, který byl realizován v roce 2005 (viz Veteška, 2010). Hlavním cílem stávajícího výzkumu bylo sledovat vývoj situace na trhu práce, respektive zjistit aktuální požadavky zaměstnavatelů na kompetence, které vyžadují od svých zaměstnanců na výše uvedených pozicích.

Použitou metodou výzkumu byla analýza inzerátů nabízejících volná pracovní místa na pozici vedoucí pracovní (dále jen „manažer") a odborný specialista (v období březen až červen 2009). Analyzováno bylo 796 inzerátů nabízejících volná pracovní místa na manažerské pozice a 849 inzerátů nabízejících volná pracovní místa na pozice odborných specialistů. Do výzkumu byla zařazena pouze plošná inzerce $\mathrm{v}$ celostátních vydáních deníků Hospodářské noviny, Lidové noviny a Mladá Fronta DNES, včetně jejich samostatných a vkládaných príloh.

Bylo zjištěno, že v roce 2009 patřily mezi nejčastěji poptávané (kategorie zcela nezbytné, velmi důležité a důležité) kompetence u manažerů:

- $\quad$ komunikační schopnosti a dovednosti (100\%);

- $\quad$ profesionální vystupování a chování (100\%);

- manažerské schopnosti a dovednosti (97\%);

- $\quad$ adaptabilita (97\%);

- $\quad$ schopnost týmové práce, kooperativnost (99\%);

- $\quad$ znalost cizích jazyků (90 \%).

Mezi požadavky zaměstnavatelů na odborné specialisty patřily znalosti, dovednosti, schopnosti a osobnostní vlastnosti, které společně vytvářejí žádoucí charakteristiku profesních a generických kompetencí. Konkrétně se jednalo o: dosažené vzdělání (86 \%), získaná praxe (82 \%), znalosti cizího jazyka (67 \%) a manažerské schopnosti $(45 \%)$. Za zcela nezbytnou kompetenci považovali zaměstnavatelé komunikační schopnosti a dovednosti (77 \%), schopnost rozhodovat se $(69 \%)$, schopnost řešit problémy $(64 \%)$, schopnost nést zodpovědnost (60\%) a schopnost motivovat a vést druhé (56\%).

Dále bylo zjištěno, že pro zaměstnavatele v České republice jsou nadále nejvýznamnější tzv. speciální (specifické) profesní kompetence, především certifikované (formalizované v rámci dosažené kvalifikace) a získané v praxi. Klíčové kompetence v širším smyslu (generické kompetence) naopak skórovaly významně méně, a to i ve srovnání s průzkumem z roku 2005. Do jaké míry na to měla vliv hospodářská krize, nelze vzhledem k použité metodice zjistit.

\section{Specifikace a individualizace systému vzdělávání a rozvoje pracovníků}

Záměrem šetření provedeného Tureckiovou opakovaně v letech 2007-2008 a 2009 bylo zjištění cílů a způsobů realizace firemního vzdělávání v inovativních pracovních organizacích. Toto vzdělávání je považováno za institucionální oporu učení pracovníků, které vede $\mathrm{k}$ optimalizaci jejich rozvojového potenciálu a ke změnám ve struktuře jejich kompetencí. Pro sumarizaci zjištěné situace a tedy i výsledků šetření byla využita upravená matice firemního vzdělávání (viz dále obrázek 3). 
Vzorek v tomto př́padě sestával z 240 respondentů, manažerů rozvoje lidských zdrojů, eventuálně specialistů firemního vzdělávání, z 220 zaměstnavatelských organizací v ČR, $\mathrm{s}$ minimálně 50 zaměstnanci, z různých segmentů národního hospodářství. Základní použitou technikou byly ohniskové skupiny; doplňující částečně strukturované rozhovory s dalšími 10 manažery lidských zdrojů. Cílem těchto rozhovorů bylo ověřit a eventuálně doplnit dříve získané výstupy.

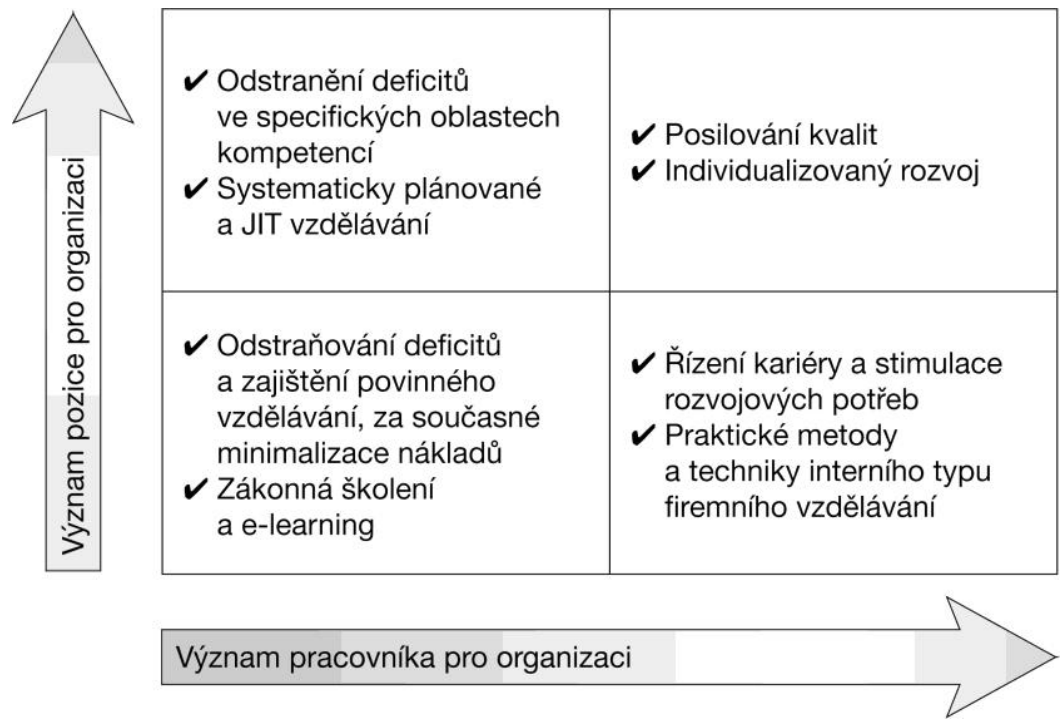

Obrázek 3. Výsledky výzkumného šetření firemního vzdělávání - záměr a hlavní aktivity. Upraveno podle Hroník (2007, s. 141 - textace v segmentech Tureckiová).

Vzhledem ke zvolené metodice výzkumu nelze v tomto př́ipadě zjištění generalizovat. Dle našeho mínění však přinejmenším naznačují trend, který se po roce 2009 , kdy došlo na českém trhu dalšího vzdělávání vlivem ekonomické recese k ústupu od systematicky prováděného vzdělávání pracovníků, u inovativních organizací začal znovu významněji projevovat od roku 2010. Tento předpoklad se dále pokusíme ověřit v navazujících výzkumech trendů ve vzdělávání a rozvoji pracovníků a v požadavcích na jejich kompetence.

\section{Závěr}

Cílevědomé vzdělávání a všechny typy učení zaměřené na kompetence umožňují jedincům snazší orientaci v prostředí změny, potenciálně lepší uplatnění v pracovním životě a dávají jim možnost zůstat aktivní $v$ průběhu celého života. V České republice roste význam kompetencí ve vzdělávání a zejména v oblasti rozvoje a řízení lidských zdrojů. Svědčí o tom řada teoreticky a metodologicky propracovaných textů, ale i nepřeberné množství př́íkladů z podnikatelské praxe. Záměrem zde prezentovaných výstupů z výzkumů bylo přinejmenším $\mathrm{v}$ dílčích ohledech ověřit některé teoretiky sdílené, ale i rozporované koncepty o směřování vývoje v oblasti profesního vzdělávání. Na obě šetření již nyní navazují v časové řadě další, využívající popsanou metodiku a dále podrobněji zpracovávající situaci $v$ uvedeném segmentu celoživotního učení v ČR. 


\section{Literatura}

Hroník, F. (2007). Rozvoj a vzdělávání pracovníků. Praha: Grada Publishing.

Palán, Z. (2002). Lidské zdroje - výkladový slovnik. Praha: Academia.

Tremblay, D. et al. (2002). Learning throughout life. Gouvernement du Québec: Ministére de 1 Éducation.

Tureckiová, M. (2009). Rozvoj a ř́zení lidských zdrojů. Praha: UJAK v Praze.

Veteška, J., \& Tureckiová, M. (2008). Kompetence ve vzdělávání. Praha: Grada Publishing.

Veteška, J. et al. (2009). Nové paradigma v kurikulu vzděláváni dospělých. Praha: Educa Service.

Veteška, J. (2010). Kompetence ve vzděláváni dospělých - pedagogické, andragogické a sociální aspekty. Praha: UJAK v Praze.

\section{Kontakt}

PhDr. Michaela Tureckiová, CSc.

Univerzita Karlova v Praze

Filozofická fakulta, Katedra andragogiky a personálního řízení, nám. J. Palacha 2, 11638 Praha 1

e-mail: michaela.tureckiova@ff.cuni.cz

Doc. PhDr. Jaroslav Veteška, Ph.D.

Univerzita Pardubice

Fakulta filozofická, Katedra věd o výchově

Studentská 97, 53210 Pardubice-Stavařov

e-mail: jaroslav.veteska@upce.cz

\section{Bibliografické údaje}

Tureckiová, M., \& Veteška, J. (2011). Význam kvalifikací a kompetencí v profesním vzdělávání dospělých. In T. Janík, P. Knecht, \& S. Šebestová (Eds.), Smišený design v pedagogickém výzkumu: Sborník př́spěvků z 19. výročni konference České asociace pedagogického výzkumu (s. 62-67). Brno: Masarykova univerzita.

Dostupné z: http://www.ped.muni.cz/capv2011/sbornikprispevku/tureckiovaveteska.pdf doi: 10.5817/PdF.P210-CAPV-2012-79 